\title{
Application of the Multi-Criteria Analysis in the Process of Road Route Evaluation
}

\author{
Siniša VILKE, Ljudevit KRPAN, Marin MILKOVIĆ
}

\begin{abstract}
The problem of road route evaluation in the process of planning and designing is reduced to making a decision regarding route selection which is preceded by a detailed analysis of each potential alternative assessed by experts. The aim of this paper is to show that conclusions regarding the evaluation and selection of the adequate road transport route can be obtained by the application of the multi-criteria analysis. In order to fulfill our research aim, a model which includes criteria and sub-criteria for road route selection is set. The defined model can be applied in the decision-making process related to the road route evaluation and selection. Its value lies in the elaborated methodology of the multi-criteria optimization applied in the transport planning and designing. The defined model was applied in the evaluation and selection of the Jelšane - Postojna highway route by using the PROMETHEE II method for the multi-criteria ranking of alternatives.
\end{abstract}

Keywords: Jelšane-Postojna highway; multi-criteria analysis; planning and designing; road route evaluation

\section{INTRODUCTION}

The construction of the highway between Trieste and Koper to Rijeka is a prerequisite for the development of the North Adriatic Port system, which should compete with the large North and West European ports. For the final highway connection of the Rijeka and Trieste ports, it is necessary to carry out the construction project of the Jelšane - Postojna section.

The research subject of this paper is the application of the optimization model for road route selection by using the method for the multi-criteria ranking of alternatives on a concrete example, i.e. the Rijeka - Koper highway. The aim of the paper is to show the conclusions that can be obtained with the application of the multi-criteria analysis regarding the road transport route evaluation in the planning and designing procedure.

In respect with the research subject, the following hypothesis has been set: for the evaluation and selection of an optimal road transport route, the method for a multicriteria ranking of alternatives can be applied.

The multi-criteria optimization method includes the analysis of more than one criterion at the same time. As support in the decision-making process, this method has been in use for a number of years in different fields of civil engineering (water management, construction management, road building, etc.). Today it is being increasingly used in the field of transport planning and designing.

The analysis and evaluation of different road route alternatives are performed within the designing project. Given that the highway between Rijeka and Trieste is still under construction on the Slovenian route between Jelšane and Postojna, potential alternatives of this route are determined and analyzed. The criteria groups and the subcriteria for the evaluation and selection of road transport route were defined on the basis of qualitative assessment by the experts. Having defined the adequate attributes of each sub-criterion value for each alternative and by applying weighting coefficients of the criteria and subcriteria for the road route selection, the evaluation of alternatives and ranking by the multi-criteria analysis has been done.

Marković, Lj. et al. [1] have developed a methodology for the selection of the highway route that is based on multi-criteria evaluation methods. The verification of the proposed methodology was conducted on the example of the selection of one of the alternative solutions offered for the E-763 highway route Belgrade-South Adriatic (Požega-Boljare section). The ranking of variants was carried out considering 12 criteria which form the basis for evaluating the variant solutions. The proposed methodology applies a combination of quantitative and qualitative assessments and the multi-criteria decision making was performed using the VIKOR method. This method emphasis is on the selection of a variant in the presence of conflict criteria, and the solution that is chosen is the one that is the closest to the ideal solution, on the basis of the adopted measure of distance. [2]

\section{MULTI-CRITERIA ANALYSIS - METHODOLOGY AND APPLICATION}

Each multi-criteria problem consists of many different and in most cases contradictory criteria that could be of different significance for the decision-maker. Most methods for the selection of the best alternative, i.e. methods for the multi-criteria decision-making require information about the relative significance of each criterion [3]. The significance estimation of the criteria is assigned by the decision-maker himself or it is based on the opinion of the group of experts.

General features of any multi-criteria problem, different from one-criterion problems, consist of the following elements:

- more decision-making criteria (objective function, criteria function),

- more alternatives (solutions) to select from,

- the process of the selection of one alternative.

The prerequisite for the application of the multicriteria analysis in transport planning and designing is the determination of the criteria and their significance and function, whose modification can lead to the perception of their impact to the selection of the optimal transport route. With preferences being a relatively subjective factor, the intentions of a decision-maker are taken into consideration by defining the significance of the criteria in respect to their weighting coefficients. Since the procedure either 
maximizes or minimizes the criteria function, the method is also called the multi-criteria optimization.

The application of the multi-criteria analysis is acceptable under the following conditions: [4]

1) a detailed defining of the criteria and an objective evaluation of their importance,

2) a detailed development of variant solutions, i.e. an equal level of the processing of criteria for each variant, on the basis of which a mutual comparison of variants in relation to the fulfillment of certain criteria is possible,

3) an evaluation of all variants according to the defined criteria.

\subsection{Application of the Multi-Criteria Analysis in Transport Planning}

Since in practice transport experts are not the only ones participating in selecting the optimal variants in transport planning and designing, but the officials at various decision-making levels who do not have to have specialized expertise also play an important role, the multicriteria optimization represents a useful tool for presenting an optimal solution with defined assumptions. One of the most important prerequisites for achieving the desired effects of management and decision-making is making quality problem solving decisions in every phase. A decision maker is usually a natural or legal person who is responsible for the adoption of a final optimal solution or variant. Their main role is to define the criteria and preference structure and, with the help of experts, select a final version. The structure of the decision-makers' preference is generally based on technical, economic, social and political criteria. If the preference structure is familiar before the optimization process, the decisionmaking process is relatively simple, and in the case of changes in the structure during the process, the process becomes much more complex. [5]

The final and decisive role in the multi-criteria optimization is the one of decision-makers. Decisionmaking at the strategic, tactical and operational level is associated with different developmental goals. The strategic level of decision-making is more complex because of the effects those decisions have on the development of a region or a country, and requires a macro territorial approach in the study.

In practice, there are often conflicts of desired goals at the strategic level. What usually happens is that the goals coming from the surroundings and mainly representing the administrative constraints, or the necessity of coordination with the existing spatial and other plans of a geographical area, are in conflict with the internal goals generated within the system. The described conflict is transferred to the criteria, and is then caused primarily by a poor structuring of a problem. The conflict between the criteria emphasizes the need for applying the methods of the multi-criteria analysis, since classical methods, including intuitive decision-making, cannot determine an optimal solution to the problem.

When analyzing the application of certain criteria in the procedures of transport planning and designing, it is clear that there are no dominant criteria, and that their importance varies depending on each individual problem.
The fact is that investments in the transport infrastructure are becoming increasingly complex due to the impact of a large number of parameters on the investment efficacy and a very variable environment in which the project is conducted. It is certain that in almost all investments, including transportation and economic and industrial buildings, the increasing importance is given to the environmental criteria.

The multi-criteria optimization as the process of selecting the best scenario implies that the variant that gives the optimum value of the objective function according to the predetermined criteria is selected as the best or optimal variant. [6]

The multi-criteria analysis method provides significant help in the decision-making process. The problem of selecting the optimal solutions in transport planning and designing is very complex since all the conditions, which include physical, geographical, ecological, economic, technical, technological and other conditions, should be thoroughly considered.

\subsection{PROMETHEE Method: Theoretical Background}

Many of the multi-criteria optimization procedures include methods for a multi-criteria ranking of the application of the solution which is aimed at determining the ranking schedules of variants based on the satisfaction level of the defined criteria. These procedures can be categorized according to different aspects, e.g. according to the shape of the model (e.g. linear, nonlinear, stochastic), according to the spatial characteristics (e.g. finite or infinite), or the alternatives presented (e.g. pre-specified preferences or interactive). [7]

The purpose of variant ranking is the reduction of the decision-making area and the quantified representation of facts that are important during the decision-making procedure. The multi-criteria ranking is particularly significant in the decision-making process of the selection of an optimal variant from a set of variants that differ depending on the acquired criteria.

One of the most significant methods of the multicriteria analysis is the PROMETHEE method. This method has successfully been used in many decision-making problems comprising transport planning and designing. Behzadian, M. et al. [8] provide a list of scientific publications, researches, applications and discussions related to the PROMETHEE method.

The basic postulates on which the PROMETHEE (Preference Ranking Organization METHod for Enrichment Evaluations) method for a multi-criteria ranking of variants is based are the following [9]:

1) Coverage of the criteria

2) Estimated relation of a higher rank

3) Use of a relation of a higher rank.

The coverage of the criteria involves the formation of the preferences of the decision-maker, modified in such a way that each criterion is observed through six possible functions of preference (six different types of criteria) based on the intensity of the preference. Some of them allow intransitivity of indifference, while others provide smooth or impulsive transfer from indifference to strict preference. In other words, the first postulate implies the 
definition of the type of criteria within the six possible functions of preference.

The use of criteria formed in this way allows the construction of an estimated relation of a higher rank. The relation of a higher rank is less sensitive to minor changes of parameters and its interpretation is rather simple.

The use of a relation of a higher rank implies a specific use of an estimated relation of a higher rank, especially in the case of variants which have to be ranked from the best to the worst ones. Thus, the PROMETHEE I method allows a partial ranking of variants, namely, the ranking which enables different variants to be at the same rating, thus allowing the utilization of certain ranks. Complete ranking, in which each variant is distinctly ranked in dependence to the function of preference, may be achieved by means of the PROMETHEE II method. [10]

The method PROMETHEE II is mostly used in practical application in transport planning and designing because it allows ranking determination. This method, on the basis of the exact data input, allows both a partial and complete ranking of a large number of alternatives with respect to the larger number of criteria.

If the decision-maker requires the complete sequence of alternatives, namely their complete ranking without contrast, that means it is not possible that two or more alternatives would be equally ranked (each alternative has its own rank). Hence, for each solution $a \in A$, the net flow is:

$$
\phi(a)=\phi^{+}(a)-\phi^{-}(a)
$$

and for the solution ranking, it could be simply applied that:

- $a$ has a higher rank than $b\left(a P^{(2)} b\right)$ if $\varphi(a)>\varphi(b)$

- $a$ is indifferent to $b\left(a I^{(2)} b\right)$ if $\varphi(a)=\varphi(b)$

The PROMETHEE II method for the multi-criteria ranking of alternatives gives the complete relation in which all the alternatives are completely ranked. The existence of a higher abstraction degree is the result of the fact that in this relation, part of information is lost due to the balanced effects between the input and output flow.

\section{MODEL FOR THE EVALUATION OF A ROAD ROUTE}

Given that the quality of the implemented selection procedure for the best road route variant and the accuracy of the final decision directly depend on the quality of the selected criteria, it is very important to determine well the criteria and measures for the optimization implementation. Experts must participate in defining the criteria to ensure that the assessment of the criteria importance does not succumb to a subjective approach [11].

The most significant way for dividing the criteria for the evaluation and selection of the road traffic route is the one that makes a difference between the variants of the evaluation of the criteria. According to that, there are two different sets of criteria:

- a set of criteria that is evaluated on the basis of concrete, exact and quantitatively expressed data,
- a set of criteria that is evaluated on the basis of the subjective opinion of researchers who are assumed and required to have sufficient knowledge of the problems and criteria that they will be evaluating.

To set up a model for the evaluation and selection of the road route, the criteria groups and sub-criteria have been defined and their evaluation, i.e. the assigning of weighting coefficients has been performed.

For the purposes of the evaluation and selection of the road routes and the implementation of the multi-criteria optimization method, thematic groups of criteria and subcriteria were defined as well as the settlement of their importance according to the information obtained from interviews held with a large number of experts, i.e. 18 planners and designers and 7 scientific researches in the field of traffic planning.

The criteria for the evaluation of road routes are divided into five thematic groups that are divided into less complex components or sub-criteria. This allows a more quality access of the multi-criteria variant ranking, as well as the possibility of the results analysis and conclusions ensuring the evaluation of individual transport routes.

The model for the selection of the road route which includes the thematic groups of the criteria and sub-criteria for evaluation and their assigned weighting coefficients (of importance) is shown in Tab. 1.

\begin{tabular}{|c|c|c|c|}
\hline \multirow{2}{*}{\multicolumn{2}{|c|}{$\begin{array}{l}\text { CRITERIA( } \\
\%)\end{array}$}} & \multicolumn{2}{|l|}{ SUB-CRITERIA } \\
\hline & & Full name & Value \\
\hline \multirow{5}{*}{ 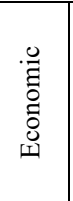 } & \multirow{5}{*}{$23 \%$} & Costs of the of the route construction & $32 \%$ \\
\hline & & Costs of maintenance & $15 \%$ \\
\hline & & Costs of management & $16 \%$ \\
\hline & & $\begin{array}{c}\text { Development of economic activities in the } \\
\text { region }\end{array}$ & $24 \%$ \\
\hline & & Impact on the wider community & $13 \%$ \\
\hline \multirow{8}{*}{ 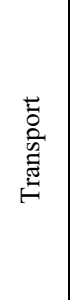 } & \multirow{8}{*}{$28 \%$} & Transport reliability and speed & $13 \%$ \\
\hline & & Transport safety & $19 \%$ \\
\hline & & $\begin{array}{c}\text { Integration into the existing road network } \\
\text { routes }\end{array}$ & $12 \%$ \\
\hline & & Integration into other transport systems & $10 \%$ \\
\hline & & Travel time for commercial vehicles & $9 \%$ \\
\hline & & Travel time for cars & $10 \%$ \\
\hline & & Route length & $16 \%$ \\
\hline & & Route position at the facilities & $11 \%$ \\
\hline \multirow{3}{*}{ 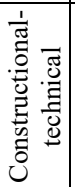 } & \multirow{3}{*}{$11 \%$} & $\begin{array}{l}\text { Technical complexity of the construction of } \\
\text { the route }\end{array}$ & $39 \%$ \\
\hline & & Terrain geology and seismology & $28 \%$ \\
\hline & & Availability of space (free land) & $33 \%$ \\
\hline \multirow{5}{*}{ 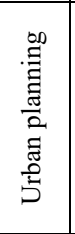 } & \multirow{5}{*}{$16 \%$} & Visual landscape impact & $25 \%$ \\
\hline & & $\begin{array}{l}\text { Impact on the development of the potential } \\
\text { in urban planning }\end{array}$ & $19 \%$ \\
\hline & & Spatial units preservation andland taking & $18 \%$ \\
\hline & & Space limitations & $19 \%$ \\
\hline & & $\begin{array}{l}\text { Damage to the relief and the possibilities of } \\
\text { recovery }\end{array}$ & $19 \%$ \\
\hline \multirow{5}{*}{$\begin{array}{l}\bar{J} \\
.0 \\
00 \\
0 \\
0 \\
0 \\
0 \\
0 \\
0 \\
0 \\
0 \\
0 \\
I\end{array}$} & \multirow{5}{*}{$22 \%$} & Noise impact & $19 \%$ \\
\hline & & Influence on the population & $23 \%$ \\
\hline & & Spatial impact & $21 \%$ \\
\hline & & Influence of meteorological conditions & $16 \%$ \\
\hline & & $\begin{array}{l}\text { Impact of the route on the water and soil } \\
\text { pollution }\end{array}$ & $22 \%$ \\
\hline
\end{tabular}

Source: Prepared by the authors.

The importance of the thematic groups of criteria is mutually compared and the weight coefficients are 
normalized so that their sum is $100 \%$. Moreover, the weighting coefficients of the sub-criteria within a certain thematic group of criteria are normalized so that the total possible sum within each group of criteria is $100 \%$.

The proposed model for the selection of the road route will be applied to rank the variant solutions of connecting the North Adriatic ports of Rijeka, Koper and Trieste by a highway.

\section{APPLICATION OF THE PROMETHEE METHOD IN THE PROCESS OF ROUTE SELECTION: JELŠANE - POSTOJNA HIGHWAY}

For the optimization of the road route selection which would connect the ports of Rijeka, Koper and Trieste, a process of the multiple-criteria ranking of variants has been applied, the method PROMETHEE II, and the computer software for the multi-criteria optimization, "Visual PROMETHEE".

For the selection of the highway route, the multicriteria analysis was implemented in four phases in the following order:

1) the determining of alternative solutions for the highway route,

2) the evaluation of individual variants in accordance with the established criteria and sub-criteria,

3) the comparison and ranking of individual variants,

4) the making of the decision on the optimal alternative solution.

In order to achieve a complete connection between the ports of Rijeka and Trieste, a Jelšane - Postojna highway section needs to be constructed. Among the specified route corridors, three variants stand out, with six additional subvariants. For the ranking variants, five solutions have been chosen. Basic technical parameters and elements are determined for each solution according to the National Spatial Plan of the Ministry of the Environment and Spatial Planning of Slovenia. [12]

By analyzing potential routes of the individual sections of the Jelšane-Postojna/Razdrto/Divača highway, five possible variants have been selected. Each of them is defined by the criteria, sub-criteria and weighting coefficient. Variants of the highway route taken into account for the multi- criteria analysis are as follows:

1) Variant I: Jelšane 2 - Ilirska Bistrica - Pivka Postojna 1

2) Variant II: Jelšane 2 - Ilirska Bistrica - Pivka Postojna 2

3) Variant III: Jelšane 2 - Ilirska Bistrica - Pivka Razdrto

4) Variant IV: Jelšane 2 - Ilirska Bistrica - Pivka Divača 1

5) Variant V: Jelšane 2 - Ilirska Bistrica - Pivka Divača 2.

Using the appropriate computer software, an optimal road transport route between the North Adriatic ports of Rijeka, Koper and Trieste will be selected. The importance of certain groups of the criteria and sub-criteria obtained by survey research and the values of the parameters of the appropriate sub-criteria for the five chosen variants of the Jelšane-Postojna highway will be used as input data.

\subsection{Analysis of Alternative Road Route Variants and Basic Procedures of the Optimization Model}

In order to analyze the five variants and properly evaluate them, they begin at the same point at the Jelšane2 junction. In Fig. 1, an overview of road route variant solutions is presented.

According to the published draft of the National Spatial Plan of the Republic of Slovenia, the starting point of the highway with the Republic of Croatia would be in Jelšane, while its junction with the highway KoperLjubljana is predicted in three possible junctions: Postojna, Razdrto or Divača. The length of the analyzed highway depends on the chosen variant and is projected to be 34-39 kilometers long. According to the project, the highway has a typical cross section with four lanes, is $3.75 \mathrm{~m}$ wide, the design speed is $120 \mathrm{~km} / \mathrm{h}$, while the minimum radius of the horizontal curve is $750 \mathrm{~m}$.

There are nine potential corridors of the Rijeka Trieste highway route through Slovenia that are being considered within the National Spatial Plan of the Republic of Slovenia, as shown in Fig 1. From the possible potential corridors, according to the characteristic run of the route and its connection with other road routes, emphasis is put on three variants:

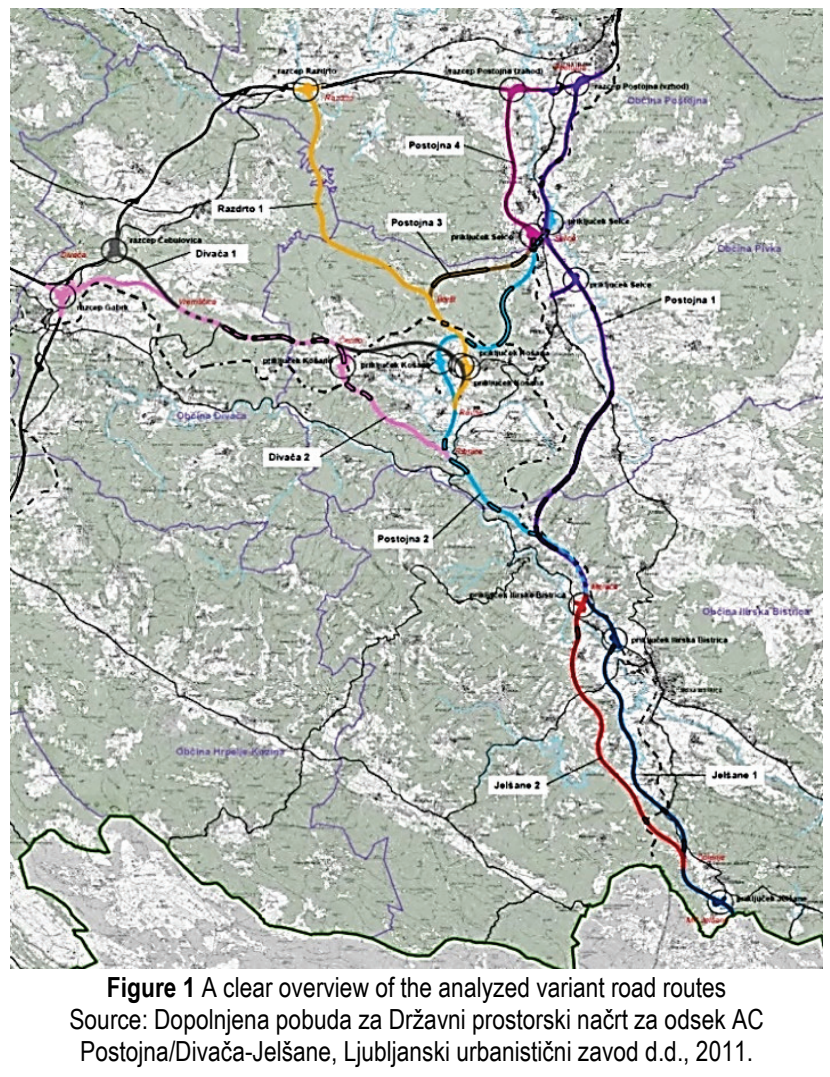

According to the Northern variant, called the Postojna variant, the highway would pass from Ilirska Bistrica to Postojna and to the junction of the Koper-Ljubljana highway. The variant that provides access to Postojna consists of four additional sub-variants. For the multicriteria ranking procedure, two sub-variants, Postojna 1 and Postojna 2, will be used. According to the second variant, the connection to the Koper-Ljubljana highway is located further south, at the Razdrto junction, while with 
the southern variant, the highway will end at the Divača junction. The Divača variant includes two additional subvariants that will be used for the multi-criteria analysis.

In accordance with the National Spatial Plan, two additional variants are provided. They follow the route immediately after the Croatian border from the junction of Jelšane to Ilirska Bistrica. Because of common technical and exploitation features and positive ratings during the public hearing, the Jelšane 2 sub-variant will be used for the multi-criteria optimization.

Further in the text, the northern variants of the route from Pivka, i.e. the Mereče junction to the north are described, along with the southern variant of the Jelšane 2 route.

The Postojna 1 variant has the length of $20960 \mathrm{~m}$ with a fold level at the height of $477 \mathrm{~m}$ at the Silentabor tunnel. The total length of the area with a longitudinal inclination of $i=5 \%$ is $1.5 \mathrm{~km}$, the total length of the tunnel is $3550 \mathrm{~m}$ and the total length of all objects is $1800 \mathrm{~m}$.

The Postojna 2 variant has the length of $24320 \mathrm{~m}$ with the fold level at the height of $583 \mathrm{~m}$ at the Ostojnica tunnel. The total length of the area with a longitudinal inclination of $i=5 \%$ is $1.4 \mathrm{~km}$, the total length of the tunnel is 2650 $\mathrm{m}$ and the total length of all objects is $2800 \mathrm{~m}$.

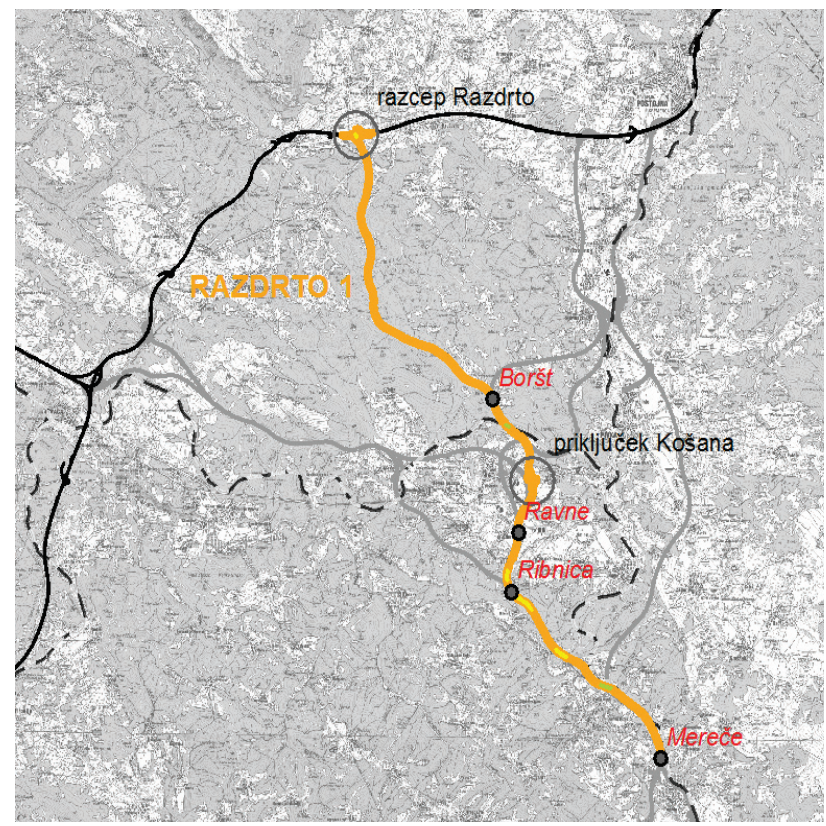

Figure 2 An overview of the variant of the Razdrto 1 road route Source: Dopolnjena pobuda za Državni prostorski načrt za odsek AC Postojna/Divača-Jelšane, Ljubljanski urbanistični zavod d.d., 2011.

The Razdrto 1 variant has the length of $23550 \mathrm{~m}$ with a fold level at the height of $653 \mathrm{~m}$ at the $5400^{\text {th }} \mathrm{m}$ of the route. The total length of the area with a longitudinal inclination of $i=5 \%$ is $3.2 \mathrm{~km}$, the total length of the tunnel is $350 \mathrm{~m}$ and the total length of all objects is 1650 $\mathrm{m}$.

The Divača 1 variant has the length of $24230 \mathrm{~m}$ with a fold level at the height of $655 \mathrm{~m}$ (between the "Žebje" and "Črnareber" tunnels). The total length of the area with a longitudinal inclination of $i=5 \%$ is $3.3 \mathrm{~km}$, the total length of the tunnel is $1650 \mathrm{~m}$ and the total length of all objects is $2700 \mathrm{~m}$.

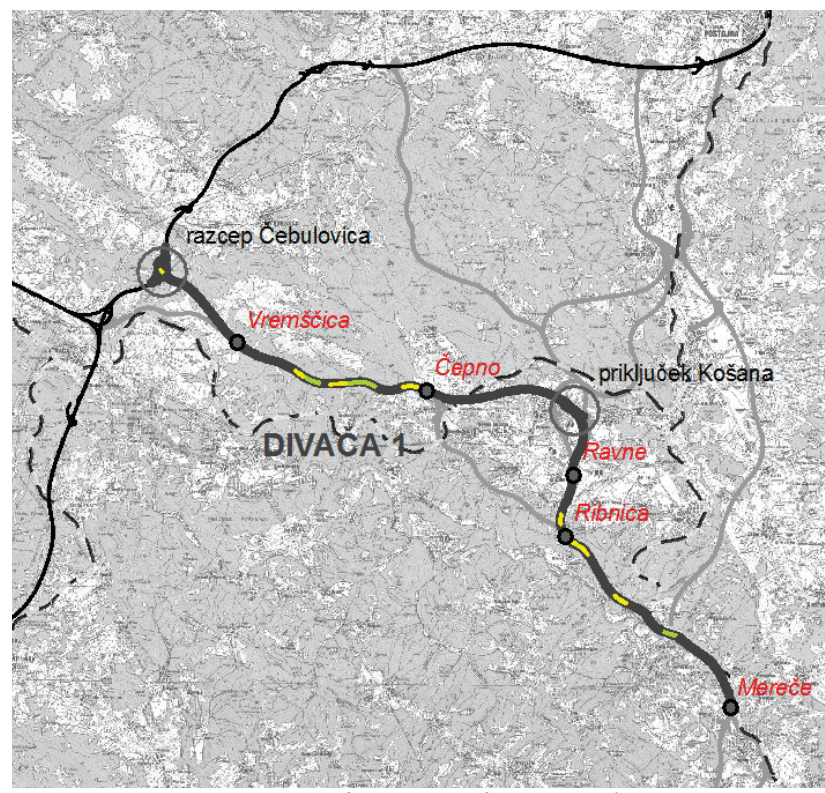

Figure 3 An overview of the variant of the Divača 1 road route Source: Dopolnjena pobuda za Državni prostorski načrt za odsek AC

Postojna/Divača-Jelšane, Ljubljanski urbanistični zavod d.d., 2011.

The Divača 2 variant has the length of $23210 \mathrm{~m}$ with a fold level at the height of $660 \mathrm{~m}$ located between the "Žebje" and "Črnareber" tunnels. The total length of the area with a longitudinal inclination of $i=5 \%$ is $7.8 \mathrm{~km}$, the total length of the tunnel is $2020 \mathrm{~m}$ and the total length of all objects is $2900 \mathrm{~m}$.

The Jelšane 2 variant has the length of $14170 \mathrm{~m}$ with a fold level at the height of $527 \mathrm{~m}$ at the $11300^{\text {th }} \mathrm{m}$ of the route. The total length of the area with a longitudinal inclination of $i=5 \%$ is $1.6 \mathrm{~km}$, the total length of all objects is $450 \mathrm{~m}$ and no tunnel construction is planned on the route.

The lengths of the variants of the northern part of the route amount to an average of $23 \mathrm{kph}$, while those in the southern part of route amount to about $14 \mathrm{kph}$.

In order to evaluate the established variant solutions of the Jelšane-Postojna/Razdrto/Divača highway on the basis of the multi-criteria analysis, parameters for each defined variant have been set. Appropriate weight coefficients have been assigned to the parameters of the sub-criteria of analyzed variants in order to examine which traffic solution and from which aspect of the evaluation criteria is the solution more favorable in relation to other variants.

The evaluation of routes according to the projected investment costs was done based on the data on their length, bottom and top layout, as well as the number, size and type of objects.

In terms of road infrastructure, the cheapest variant is the Variant III because it requires the construction of the smallest number of tunnels with the total length of only 350 $\mathrm{m}$, and its total length of objects is the smallest with the length of $2100 \mathrm{~m}$.

The construction of the route of the Variant IV, which includes the northern section of Divača 1 is the second best option because it requires the construction of a tunnel the length of $1650 \mathrm{~m}$ and its total length of objects is $3150 \mathrm{~m}$. The most expensive options for the construction of road infrastructure are the first two variants: Variant I also includes the construction of the road route through the tunnels for the length of $3550 \mathrm{~m}$ and the total length of the 
objects would be $2250 \mathrm{~m}$, while the route of the Variant II would go $900 \mathrm{~m}$ less through the tunnels, but the total length of the objects would increase by $1000 \mathrm{~m}$. Taking into consideration that the variant which includes the construction of Postojna 2 is by $3360 \mathrm{~m}$ longer than the one which includes the construction of Postojna 1, that one being Variant II, it has been estimated as the most expensive for construction. It is necessary to state that the route of Variant $\mathrm{V}$ is the one that passes through objects the most (3350 $\mathrm{m}$ in length), but the length of its passing through the tunnels is $2020 \mathrm{~m}$, which is why the subcriterion for the construction of road infrastructure for that route is evaluated with the score 5 . With the sub-criteria of reliability and the speed of traffic and traffic safety closely related, variants were evaluated according to those criteria in accordance with the existing technical elements of the routes, i.e. data on the total length of the areas with the longitudinal inclination and their curvature characteristics. The variants that require the construction of the Divača junction at the junction with the A1 Ljubljana-Kopar highway were evaluated better in terms of joining the existing routes of the road network since they allow for a shorter and faster connection with Koper that is adapted to the construction of the Adriatic-Ionian highway. Between those two routes, the higher rating was given to the Variant $\mathrm{V}$ because its connection to the existing highway is located more south, and it is also joined to the A3 Divača-Fernetiči highway.

That is how Variant III, which requires the construction of the Razdrto junction, was given the score 6 , while the two more northern variants were given lower scores. The existing network of the state roads of the Republic of Slovenia includes the G6 Postojna-Jelšana road, which, due to its constraints, takes over a smaller part of the remote freight traffic towards Rijeka, and the G7 road that takes over the majority of it. In the same way, the inclusion into other traffic systems, as a criterion which encompasses the interaction of the new highway with other traffic branches, has been evaluated. The travel time of commercial and personal vehicles was estimated based on the anticipated distance of individual variant solutions and the average travel speed, which for commercial vehicles is $90 \mathrm{~km} / \mathrm{h}$ and for passenger cars $110 \mathrm{~km} / \mathrm{h}$.

With regard to the $\mathrm{C} 19$ and $\mathrm{C} 20$ sub-criteria, it should be said that the first two variants mostly pass through the agricultural and forest areas, with the difference that the route of the Variant I mostly passes through the highquality agricultural areas. Moreover, the variants that include the northern routes to Postojna pass in the vicinity of the Prestranek economic route and they stretch across the valley of the Pivka River. The route that requires the construction of the Razdrto junction is largely located in the forest area. A section of that variant from the railway line to Ribnica passes through an agricultural area. The southern routes that include the Divača junction pass through the slopes of Vremščica and the forest area, while in vicinity of Gabrk, they pass through the agricultural areas.
Table 2 Criteria evaluation for variant solutions

\begin{tabular}{|c|c|c|c|c|c|c|c|c|}
\hline \multirow{2}{*}{\multicolumn{2}{|c|}{ Criteria (\%) }} & \multirow{2}{*}{$\begin{array}{c}\begin{array}{c}\text { Sub- } \\
\text { criteria }\end{array} \\
\text { Mark } \\
\end{array}$} & \multirow{2}{*}{$\begin{array}{l}\text { Object } \\
\text { function }\end{array}$} & \multicolumn{5}{|c|}{ Variant } \\
\hline & & & & I & II & III & IV & $\mathrm{V}$ \\
\hline \multirow{5}{*}{ 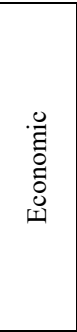 } & \multirow{5}{*}{$23 \%$} & $\mathrm{C} 1$ & $\begin{array}{l}\text { Rating } \\
\text { Min }\end{array}$ & 6 & 7 & 2 & 4 & 5 \\
\hline & & $\mathrm{C} 2$ & $\begin{array}{l}\text { Rating } \\
\text { Min }\end{array}$ & 6 & 7 & 3 & 4 & 5 \\
\hline & & $\mathrm{C} 3$ & $\begin{array}{l}\text { Rating } \\
\text { Min }\end{array}$ & 6 & 7 & 3 & 4 & 5 \\
\hline & & $\mathrm{C} 4$ & $\begin{array}{l}\text { Rating } \\
\text { Max }\end{array}$ & 5 & 5 & 6 & 7 & 7 \\
\hline & & $\mathrm{C} 5$ & $\begin{array}{l}\text { Rating } \\
\text { Max }\end{array}$ & 5 & 5 & 6 & 7 & 7 \\
\hline \multirow{8}{*}{ 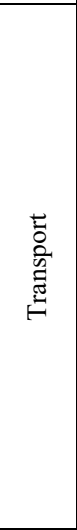 } & \multirow{8}{*}{$28 \%$} & C6 & $\begin{array}{l}\text { Rating } \\
\text { Max }\end{array}$ & 6 & 5 & 4 & 5 & 2 \\
\hline & & $\mathrm{C} 7$ & $\begin{array}{l}\text { Rating } \\
\text { Max }\end{array}$ & 6 & 5 & 4 & 5 & 2 \\
\hline & & $\mathrm{C} 8$ & $\begin{array}{l}\text { Rating } \\
\text { Max }\end{array}$ & 4 & 4 & 6 & 8 & 9 \\
\hline & & C9 & $\begin{array}{l}\text { Rating } \\
\text { Max }\end{array}$ & 5 & 5 & 6 & 7 & 8 \\
\hline & & $\mathrm{C} 10$ & $\begin{array}{l}\min \\
\text { Min }\end{array}$ & 23.4 & 25.6 & 25.2 & 25.6 & 24.8 \\
\hline & & C11 & $\begin{array}{l}\min \\
\text { Min }\end{array}$ & 19.1 & 21 & 20.6 & 21 & 20.3 \\
\hline & & $\mathrm{C} 12$ & $\begin{array}{l}\mathrm{km} \\
\text { Min }\end{array}$ & 35.1 & 38.5 & 37.8 & 38.5 & 37.4 \\
\hline & & $\mathrm{C} 13$ & $\begin{array}{l}\text { Rating } \\
\text { Min }\end{array}$ & 7 & 8 & 6 & 5 & 6 \\
\hline \multirow{3}{*}{ 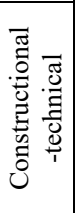 } & \multirow{3}{*}{$11 \%$} & $\mathrm{C} 14$ & $\begin{array}{l}\text { Rating } \\
\text { Min }\end{array}$ & 6 & 7 & 3 & 4 & 5 \\
\hline & & $\mathrm{C} 15$ & $\begin{array}{l}\text { Rating } \\
\text { Min }\end{array}$ & 0 & 0 & 0 & 0 & 0 \\
\hline & & $\mathrm{C} 16$ & $\begin{array}{l}\text { Rating } \\
\text { Max }\end{array}$ & 8 & 9 & 5 & 7 & 7 \\
\hline \multirow{5}{*}{ 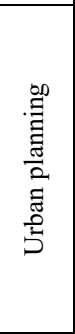 } & \multirow{5}{*}{$16 \%$} & $\mathrm{C} 17$ & $\begin{array}{l}\text { Rating } \\
\text { Min }\end{array}$ & 5 & 5 & 4 & 6 & 6 \\
\hline & & C18 & $\begin{array}{l}\text { Rating } \\
\text { Min }\end{array}$ & 5 & 5 & 6 & 4 & 4 \\
\hline & & C19 & $\begin{array}{l}\text { Rating } \\
\text { Max }\end{array}$ & 6 & 5 & 7 & 4 & 4 \\
\hline & & $\mathrm{C} 20$ & $\begin{array}{l}\text { Rating } \\
\text { Min }\end{array}$ & 4 & 3 & 6 & 7 & 5 \\
\hline & & $\mathrm{C} 21$ & $\begin{array}{l}\text { Rating } \\
\text { Min }\end{array}$ & 3 & 5 & 4 & 4 & 6 \\
\hline \multirow{5}{*}{$\begin{array}{l}\bar{J} \\
.0 \\
0 \\
0 \\
0 \\
0 \\
0 \\
0 \\
0 \\
0 \\
0 \\
0 \\
1\end{array}$} & \multirow{5}{*}{$22 \%$} & $\mathrm{C} 22$ & $\begin{array}{l}\text { Rating } \\
\text { Min }\end{array}$ & 0 & 0 & 0 & 0 & 0 \\
\hline & & $\mathrm{C} 23$ & $\begin{array}{l}\text { Rating } \\
\text { Min }\end{array}$ & 4 & 4 & 5 & 5 & 5 \\
\hline & & $\mathrm{C} 24$ & $\begin{array}{l}\text { Rating } \\
\text { Min }\end{array}$ & 5 & 5 & 6 & 7 & 7 \\
\hline & & $\mathrm{C} 25$ & $\begin{array}{l}\text { Rating } \\
\text { Min }\end{array}$ & 3 & 5 & 6 & 8 & 8 \\
\hline & & $\mathrm{C} 26$ & $\begin{array}{l}\text { Rating } \\
\text { Min }\end{array}$ & 3 & 4 & 5 & 6 & 6 \\
\hline
\end{tabular}

Source: Prepared by the authors.

The analyzed routes of variants pass several times over a large number of watercourses and their tributaries, among which the most important ones are Molja, Pivka and Reka. Moreover, in the passage areas of the variants there are protected areas of water sources. According to more public hearings, it has been accepted that the three southern variants, Razdrto, Divača 1 and Divača 2, are not acceptable for ecological reasons. That can be seen from the ecological-sociological sub-criteria that give advantage to the connection to the A1 highway in Postojna, i.e. Variant I. Experts estimate that the northern solutions have less influence on the groundwater pollution and soil pollution and degradation compared to the Razdrto variant, while the variants that include the connection in Divača were evaluated as being the least favorable with respect to 
the above-mentioned sub-categories. The northern variants achieve a better synergy with the natural landscape, while variants IV, V and especially III degrade the space more and distort the appearance of the landscape.

\subsection{Selection of an Optimal Highway Route}

For selecting the optimal highway route that would connect the ports of Rijeka, Koper and Trieste between the five proposed variant solutions, the values of the subcriteria defined in the previous chapter have been entered in the computer software for multi-criteria optimization called "Visual PROMETHEE". The values of the importance of groups of criteria and the sub-criteria evaluated by experts have also been entered in the software.

Two different scenarios have been developed for the purpose of the multi-criteria optimization. For the first scenario, the weighting coefficients of the thematic groups of criteria and sub-criteria according to the model set out in Chapter 3 have been used. The second scenario puts more emphasis on the planning criteria, which is why higher coefficients of importance have been assigned to the group of urban planning criteria, and thus, their weight coefficient is $24 \%$. Furthermore, the weight coefficients of $21 \%$ were assigned to the economic criteria, of $26 \%$ to the transport criteria, of $9 \%$ to the constructional-technical criteria and of $20 \%$ to the eco-sociological criteria.

\begin{tabular}{|c|l|r|r|r|r|}
\hline Rank & \multicolumn{2}{|c|}{ action } & Phi & Phì & Phi- \\
\hline $\mathbf{1}$ & Variant 1 & $\square$ & 0,2009 & 0,5253 & 0,3244 \\
\hline $\mathbf{2}$ & Variant 3 & $\square$ & 0,1190 & 0,5037 & 0,3847 \\
\hline $\mathbf{3}$ & Variant 4 & $\square$ & $-0,0103$ & 0,3756 & 0,3859 \\
\hline $\mathbf{4}$ & Variant 5 & $\square$ & $-0,0938$ & 0,3574 & 0,4512 \\
\hline $\mathbf{5}$ & Variant 2 & $\square$ & $-0,2158$ & 0,2931 & 0,5090 \\
\hline
\end{tabular}

Figure 4 An overview of the result of Scenario 1 of the multi-criteria analysis of the evaluation of the Rijeka - Koper - Trieste highway route section. Source: Prepared by the authors

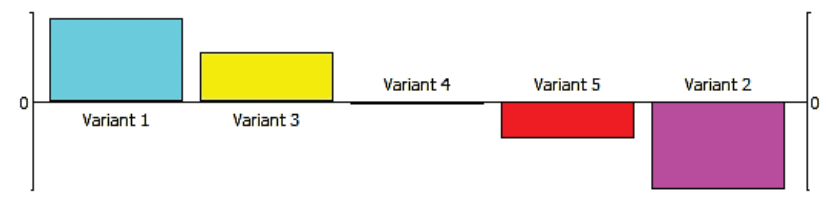

Figure 5 Overview of the Scenario 1 of the multi-criteria analysis of the evaluation of the Rijeka - Koper - Trieste highway route section. Source: Prepared by the authors

All the sub-criteria of evaluation are defined as Type 1 criteria for which it is not necessary to define additional parameters that specify the exact function of preferences. The multi-criteria optimization method PROMETHEE I brings calculated Phi values, i.e. input (-) and output (+) flows or the relations of the dominance of certain pairs of actions. On the other hand, the PROMETHEE II method for the multi-criteria analysis gives the final obtained ranking of variants based on the calculation of the net value of Phi.

Fig. 4 shows the obtained values for each individual variant and their positive and negative value of Phi. A graphic overview of the numerical values of net flows is shown in Fig. 5. The analyzed variants are ranked in the following order: Variant 1 with a value of net flow of 0.20 is the optimal choice; Variant 3 with the value of the net flow of 0.11 is the second ranked selection, while the third place is occupied by the Variant 4 with the value of the net flow of -0.01 . Variants 5 and 2 have an expressed negative net flow. Therefore, for the selection of the appropriate road route, the priority should be given to Variants 1 and 3 . However, the final choice will depend on the decisionmaker and the goals that have been set.

Best results shown by Variant 1 derive from the better rated values of transport criteria, i.e. transport reliability, speed and safety, as well as the shortest length of the route and estimated time of travelling. Moreover, Variant 1 is evaluated as the best one in terms of ecological and sociological criteria. The Variant 3 is also suitable for the selection of the highway route because it dominates according to the economic criteria among which it achieved the best results. On the other hand, Variant 2 has many shortcomings, such as: great technical complexity of construction, significant total length of the tunnel and the maximum total length of objects, the largest estimated costs of investment and exploitation, and is therefore the least appropriate for the selection.

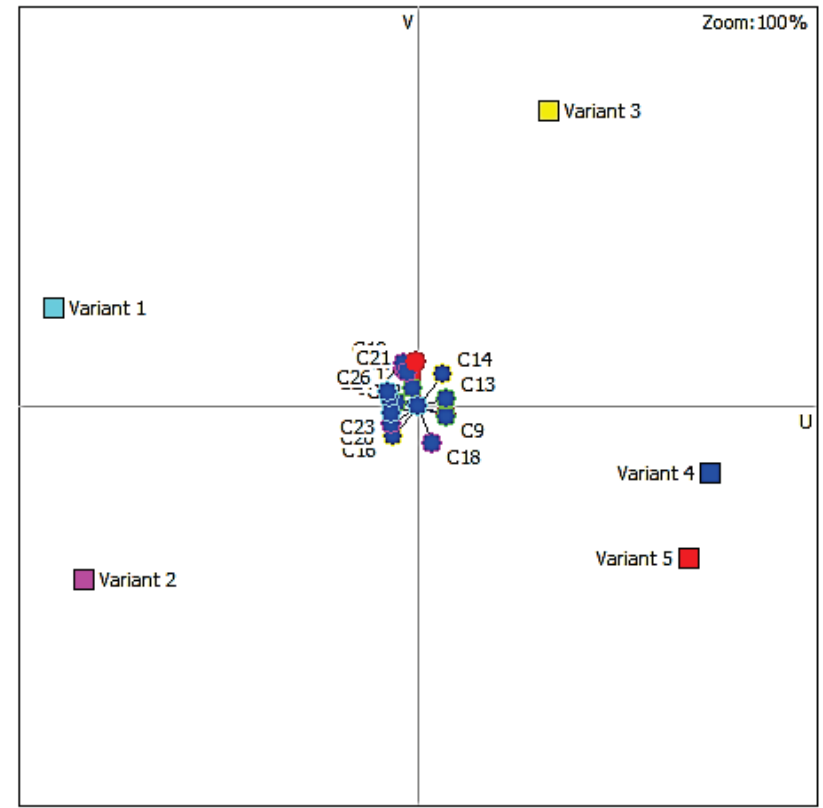

Figure 6 An overview of the result of the Scenario 1 of the multi-criteria analysis in the GAIA plane.

Source: Prepared by the authors

A direct interpretation of the multi-criteria analysis in the GAIA ("Geometrical Analysis for Interactive Aid") "u, $\mathrm{v}$ " plane is shown in Fig. 6. The clustering of variants signifies their similarities in terms of numerical values, while the dispersion means their diversity. The same applies for the sub-criteria: mutually closer sub-criteria have similar numerical characteristics.

The direction of the majority of the Variant 1 subcriteria vectors implies its domination and the direction of the decision axis (red vector) prioritizes Variant 1 over other variants. The vector axes of individual sub-criteria are dispersed, meaning that they are influencing the respective variant with different intensities. Analogously, the closing or coinciding sub-criteria are equally affecting the respective variant. 
Fig. 7 shows the results of the values for individual variants on the basis of which their ranking is done for Scenario 2 which emphasizes the importance of the urban planning criteria. The values of the net flows give the same order as the processing of Scenario 1. The results for Variant 1 and 3 are nearly equal to the obtained values in Scenario 1; moreover, they increase their dominance over the Variant 4.

\begin{tabular}{|c|l|l|r|r|r|}
\hline \hline Rank & \multicolumn{2}{|c|}{ action } & Phi & Phì & Phi- \\
\hline $\mathbf{1}$ & Variant 1 & $\square$ & 0,2222 & 0,5379 & 0,3157 \\
\hline $\mathbf{2}$ & Variant 3 & $\square$ & 0,1288 & 0,5115 & 0,3827 \\
\hline $\mathbf{3}$ & Variant 4 & $\square$ & $-0,0437$ & 0,3607 & 0,4043 \\
\hline $\mathbf{4}$ & Variant 5 & $\square$ & $-0,1250$ & 0,3436 & 0,4686 \\
\hline $\mathbf{5}$ & Variant 2 & $\square$ & $-0,1823$ & 0,3144 & 0,4967 \\
\hline
\end{tabular}

Figure 7 An overview of the result of Scenario 2 of the multi-criteria analysis of the evaluation of the Rijeka - Koper - Trieste highway route section. Source: Prepared by the authors

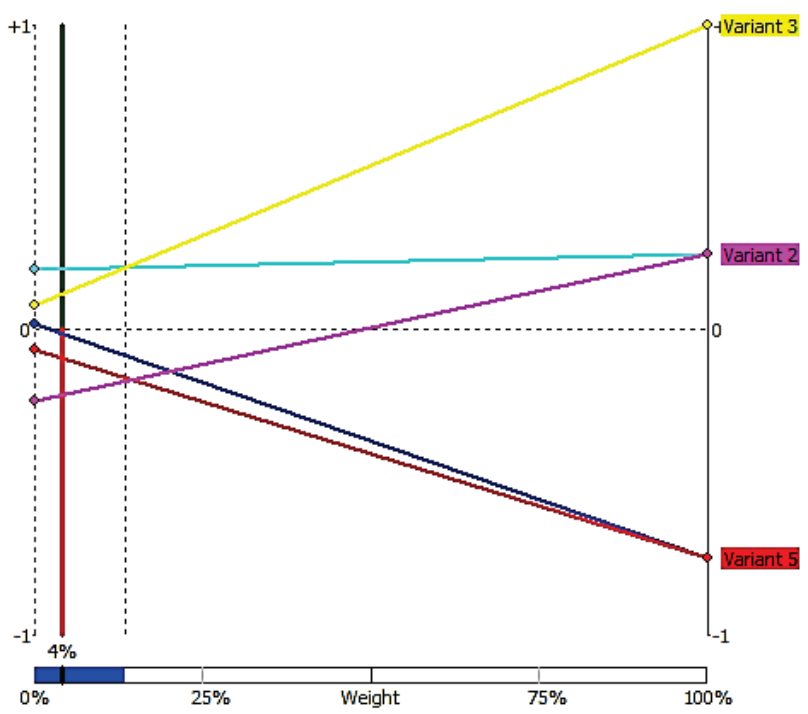

Figure 8 Sensitivity analysis of the visual landscape impact sub-criteria weight. Source: Prepared by the authors

Since the Scenario 2 does not affect the variant ranking, in Fig.8 the sensitivity analysis of the visual landscape impact sub-criteria is shown, i.e. how the order is changed with the different importance of the visual landscape impact sub-criteria. This analysis represents the lowest limit or range within which the importance of subcriteria can be changed without affecting the established order of the sub-criteria. The Weight Stability Interval (WSI), i.e. the weight interval within which the ranking remains unchanged, has the range from 0 to $13.44 \%$.

\section{CONCLUSION}

Significant and complex work that precedes the process of the multi-criteria analysis consists of gathering data on the specific criteria for the evaluation of the selected road routes. First, it is important to determine whether adequate sources are available, because for the immeasurable criteria or those sources that are not covered by exact data, a subjective assessment is conducted, which requires a detailed knowledge of the issue and an argumentative evaluation of the researchers.
The defining of thematic groups of the criteria and subcriteria for the evaluation and selection of the road traffic route and the appropriate weighting coefficients has been done on the basis on the information obtained from a large number of experts, scientific researches, planners and designers in the field of road traffic planning. A model set in that way can be applied in the process of road route evaluation.

Via a quantitative and qualitative evaluation of the criteria and sub-criteria, the efficiency and effectiveness of the model have been tested on the example of the highway route selection for Jelšane-Postojna.

With the implementation of the method of the multicriteria variants ranking, more precisely the PROMETHEE method, the evaluation and selection of the highway traffic route linking Rijeka, Koper and Trieste has been conducted, thus confirming the hypothesis set in the introduction to this paper. A successful testing of the model that includes the criteria and sub-criteria for the selection of an optimal road route confirms the importance of using the multi-criteria analysis. The research results confirm the importance of applying the multi-criteria analysis method in decision-making for space-traffic plans and projects.

Analyzing the results obtained by the multi-criteria analysis, the priority of selection of the highway route that would connect the ports of Rijeka, Koper and Trieste should be given to Variant 3, i.e. the alternative that includes the junction with the Koper-Ljubljana at the Postojna 1 junction.

The cause behind that is the fact that the specified route is better evaluated in terms of transport criteria, i.e. transport speed, reliability and safety, as well as the estimated time of travelling and shortest length. Moreover, the implementation of this route includes favorable ecological, sociological and urban planning features.

\section{REFERENCES}

[1] Marković, Lj., Milić Marković, Lj., Mitrović, S., \& Stanarević, S. (2017). The evaluation of alternative solutions for the highway route E-763 Belgrade - South Adriatic: a case study of Serbia. Tehnički vjesnik, 24(6).

[2] Opricović, S. \& Tzeng, G. H. (2007). Extended VIKOR Method in Comparison with Outranking. European Journal of Operational Research, 178(2), 514-529. https://doi.org/10.1016/j.ejor.2006.01.020

[3] Roubens, M. (1982). Preference relations on actions and criteria in multi-criteria decision making. European Journal of Operational Research, 10, 51-55. https://doi.org/10.1016/0377-2217(82)90131-X

[4] Krpan, Lj., Vilke, S., \& Milković, M. (2017). A model of the selection of an optimal railroad route by applying the multiple-criteria analysis. Tehnički vjesnik, 24(4), 11551164. https://doi.org/10.17559/TV-20160310153549

[5] Deluka-Tibljaš, A., Karleuša, B., \& Dragičević, N. (2013). Review of multicriteria-analysis methods application in decision making about transport infrastructure. Građevinar, 66(7), 619-631.

[6] Lu, J., Zhang, G., Ruan, D., \& Wu, F. (2007). MultiObjective Group Decision Making Methods, Software and Applications with Fuzzy Set Techniques. Imperial College Press, London. https://doi.org/10.1142/p505

[7] Shelton, J. \& Medina, M. (2010). Integrated MultipleCriteria Decision Making Method to Prioritize Transportation Projects, Transportation Research Record. 
Journal of the Transportation Research Board, 2174, 51-57. https://doi.org/10.3141/2174-08

[8] Behzadian, M., Kazemzadeh, R. B., Albadvi, A., \& Aghdasi, M. (2010). PROMETHEE: A Comprehensive Literature Review on Methodologies and Applications. European Journal of Operational Research, 200(1), 98-215. https://doi.org/10.1016/j.ejor.2009.01.021

[9] Brans, J. P., Vincke, B., \& Mareschal, B. (1986). How to Select and How to Rank Project: The PROMETHEE Method. European Journal of Operational Research, 24, 207-218. https://doi.org/10.1016/0377-2217(86)90044-5

[10] Brans, J. P. \& Mareschal, B. (2005). Promethee Methods. In: Multiple Criteria Decision Analysis: State of the Art Surveys. International Series in Operations Research \& Management Science, 78. Springer, New York, 163-186. https://doi.org/10.1007/0-387-23081-5_5

[11] Vilke, S., Baričević, H., \& Maglić, L. (2013). Kriteriji za vrednovanje kopnene prometne trase. Suvremeni promet: časopis za pitanja teorije i prakse prometa, 33(5-6), 422430.

[12] (2011). Dopolnjena pobuda za Državni prostorski načrt za odsek AC Postojna/Divača-Jelšane, Ljubljanski urbanistični zavod d.d.

\section{Contact information:}

Siniša VILKE, PhD, Assistant Professor

The Faculty of Maritime Studies of the University of Rijeka

Studentska ulica 2, 51000 Rijeka, Croatia

E-mail: svilke@pfri.h

Ljudevit KRPAN, PhD, Associate Professor

Primorje-Gorski Kotar County,

Adamićeva 10, 51000 Rijeka, Croatia

E-mail: ljudevit.krpan@pgz.hr

Marin MILKOVIĆ, PhD, Professor

University North,

Trg dr. Žarka Dolinara 1, 48000 Koprivnica, Croatia

E-mail: mmilkovic@unin.hr 